УДК 316.774:321]329.09.5

\author{
Кочубей Лариса Олександрівна \\ https://orcid.org/0000-0002-8113-9068 \\ доктор політичних наук, професор, \\ провідний науковий співробітник \\ Інституту політичних і етнонаціональних \\ досліджень ім. I. Ф.Кураса НАН Украӥни, \\ Киї, Україна, \\ larisalkochubey@ukr.net
}

\title{
ЗОВНІШНІ ІНФОРМАЦІЙНО-КОМУНІКАТИВНІ ВПЛИВИ: ВИКЛИКИ ДЛЯ УКРАЇНИ
}

Метою статті є дослідити спектр технологій, які використовує проти України Російська Федерація та з'ясувати, які 3 них сьогодні $\epsilon$ особливо дієвими та руйнівними. Для проведення данного дослідження були використані методи: структурно-функціональний, емпіричний та порівняльний. Це дозволило з'ясувати особливості пропагандистських впливів на громадян України та сутність інформаційних технологій, які використовує РФ протягом останніх років. Зроблено висновок, що проблема застосування інформаційно-маніпулятивних технологій Російською Федерацією в процесі захоплення Кримського півострова, «хозяйнування» на Донбасі, претензії на Приазов'я наразі є надзвичайно актуальною 3 огляду на дуже негативні наслідки їх деструктивного впливу на свідомість громадян як України, так і світу. Особливої уваги потребує розгляд даної теми за умов розгортання гібридних війн. Росія в процесі анексії Криму активно застосовувала вагомий арсенал маніпулятивних інформаційних прийомів і досить часто досягала своїх результатів, а саме: дестабілізувати українське суспільство, унеможливити розвиток нашої держави шляхом демократичної модернізації та проведення ефективних економічних та соціальних реформ.

Зроблено висновок, що сьогодні, у час активного розвитку інформаційного суспільства інформаційно-комунікативні впливи $є$ важливим інструментом, який можна використовувати як для розвитку держави та нації, так і для маніпуляції та дестабілізації супротивника. Доцільним є для України подальший розвиток інформаційних технологій, національної стратегії, IT-сфери. А також обмежити усі російські пропагандистські ЗМІ і сконцентруватися на власних національних інтересах. Найкращим захистом від російських маніпуляцій має бути здатність критично мислити та фільтрувати інформацію, яка надходить взагалі з будь-яких джерел.

Ключові слова: інформаційно-комунікативний вплив, маніпулятивна технологія, Україна, РФ. 


\section{ЗОВНІШНІ ІНФОРМАЦІЙНО-КОМУНІКАТИВНІ ВПЛИВИ: \\ ВИКЛИКИ ДЛЯ УКРАЇНИ)}

Kochubei Larysa, Doctor of Political Sciences, Professor, Leading Researcher of the I. F. Kuras Institute for Political and Ethnic Studies of the National Academy of Sciences of Ukraine, Kyiv, Ukraine

External informational and communicative influences: challenges for Ukraine

The aim of the article is to investigate the range of technologies used by the Russian Federation against Ukraine and to find out which of them are particularly effective and destructive as for today. The following methods were used for this study: structurally-functional, empirical and comparative. This made it possible to find out the peculiarities of propaganda influences on Ukrainian citizens and the essence of information technologies used by the $\mathrm{RF}$ in recent years. It is concluded that the problem of the information-manipulative technologies use by the Russian Federation in the process of the Crimean peninsula annexation, "playing the master" in Donbas, and claims to the Azov Sea are currently extremely relevant from the perspective of the negative effects and their destructive influences on the consciousness of citizens in Ukraine and the world. Moreover, significant attention should be pointed on this topic in the context of the hybrid wars expansion. In the process of the Crimea annexation, Russia actively used a powerful arsenal of manipulative information technologies and often achieved its results, namely: destabilizing Ukrainian society, preventing the development of our state through democratic modernization and conducting effective economic and social reforms.

It is concluded that today, at the time of an active development of the information society, information and communication impacts become an important tool that can be used both for the development of the state and the nation and for the manipulation and destabilization of the enemy. For Ukraine, it is important to develop further information technologies, national strategy, and IT sphere. In addition, it is crucial to restrict all Russian propaganda media and concentrate on its own national interests. The best defence against Russian manipulations should be the ability to think critically and filter information that comes from any other sources.

Key words: information and communicative influence, manipulative technology, Ukraine, The Russian Federation.

Кочубей Лариса Александровна, доктор политических наук, профессор, ведущий научный сотрудник Института политических и этноначиональных исследований им. И. Ф.Кураса НАН Украинь

Внешние информационные и коммуникативные влияния: вызовы для Украины

Цель статьи - исследовать спектр технологий, которые использует против Украины Российская Федерация и выяснить, какие из них сегодня являются особенно эффективными и разрушительными. Для проведения данного исследования были использованы методы: структурно-функциональный, эмпирический и сравнительный. Это помогло определить особенности 
пропагандистских влияний на граждан Украины и суть информационных технологий, которые использует РФ на протяжении последних лет. Сделано вывод, что проблема использования информационно-манипулятивных технологий Российской Федерацией в процессе аннексии Крымского полуострова, «хозяйствования» на Донбассе, претензии на Приазовье сейчас есть чрезвычайно актуальной с учётом на очень негативные последствия их деструктивного влияния на сознание граждан как Украины, так и мира. Особенного внимания заслуживает рассмотрение данной темы в условиях распространения гибридных войн. Россия в процессе аннексии Крыма активно использовала весомый арсенал манипуляционных информационных приёмов и довольно часто достигала своих результатов, а именно: дестабилизировать украинское общество, сделать невозможным развитие нашего государства путём демократической модернизации и проведения эффективных экономических и социальных реформ.

Сделано вывод, что сегодня, во времена активного развития информационного общества информационно-коммуникативные влияния являются важным инструментом, который можно использовать как для развития государства и нации, так и для манипуляции и дестабилизации противника. Целесообразным является для Украины дальнейшее развитие информационных технологий, национальной стратегии, IT-сферы. А также, прежде всего, ограничить все российские пропагандистские СМИ и сконцентрироваться на собственных национальных интересах. Наилучшей защитой от российских манипуляций должна быть способность критически мыслить и фильтровать информацию, которая поступает вообще с каких либо источников.

Ключевые слова: информационно-коммуникативное влияние, манипулятивная технология, Украина, РФ.

Вступ. Сучасний стан розвитку інформаційно-комунікативних технологій яскраво демонструє ступінь впливу ї складників на життя всього людства. Ці технології не лише дають поштовх науково-технічному прогресу, але і $є$ основою різних негативних явищ на кшталт інформаційної війни як засобу досягнення політичних цілей країн-агресорів. Історія демонструє багато прикладів використання різноманітних методів інформаційної війни, серед яких зокрема: дезінформація, пропаганда, формування стереотипів, викривлення фактів, що у сукупності або окремо впливали на суспільну свідомість, породжували почуття паніки та як наслідок призводили до міжнаціональних конфліктів.

Аналіз останніх досліджень і публікацій. Останніми роками досить активно підіймається тема інформаційних впливів у політиці, деструктивних наслідків від маніпулятивних технологій, що пов'язано із необхідністю як теоретичного так практичного осмислення даної проблеми. Зокрема таких авторів, серед яких Г. Почепцов (Pocheptsov, 2014; Pocheptsov, 2015), Є. Магда (Mahda, 2015), М. Закіров 


\section{ЗОВНІШНІ ІНФОРМАЦІЙНО-КОМУНІКАТИВНІ ВПЛИВИ: \\ ВИКЛИКИ ДЛЯ УКРАЇНИ)}

(Zakirov, 2017) актуалізують для вирішення ряд важливих питань 3 інфомаційної безпеки держави, розкриття сутності пропаганди, перебігу гібрідних воєн. Проте, сьогодні дана тема потребує подальшого глибинного дослідження та розвитку у зв'язку з тим, що з'являються нові впливи та політичні події, які потребують комплексного розуміння сутності пробеми та іі вирішення. Тому метою даної статті $\epsilon$ дослідити спектр технологій, які використовує проти України Російська Федерація та 3'ясувати, які з них сьогодні є особливо дієвими та руйнівними.

Викладення основного матеріалу. Так, у 2014 р. на території України розпочалось справжнє збройне російсько-українське протистояння, що супроводжувалось агресивною медійною політикою Росії, спрямованою на інформаційне забезпечення сепаратистського руху на сході України.

Уже чотири роки Росія веде активну фазу неоголошеної гібридної війни проти України. Роль ІКТ у процесі розпалювання міжнаціонального конфлікту інформаційної війни між Росією та Україною - не можна недооцінювати. На даний період часу медіа є потужним інструментом пропаганди РФ. Ця ситуація посилилася на початку 2014 р., коли відбулася анексія Криму, а після нього і спроби відібрати ще дві території України, Донецьку та Луганську області, за які досі ведуться військові операції ООС (раніше АТО).

Загострення російсько-українського протистояння на початку XXI ст. визначило мас-медіа як один із найбільш вагомих засобів ведення інформаційної війни, метою якої стало забезпечення інформаційної підтримки бойових дій, формування політичних настроїв населення, стабілізація чи дестабілізація обстановки у різних регіонах України. Мас-медіа дискурс подій на Донбасі 2013-2015 рр. представлений кількома напрямами, серед яких можна виділити російськоцентричний, україноцентричний, західноцентричний, що 3 часом розділився на євроцентричний та американоцентричний. Найбільш масштабним за обсягами контенту залишається російськоцентричний дискурс, який використовується в рамках ведення інформаційної війни. Уже традиційне поняття «війна» 3 військового явища перетворилося на комунікативне. У політичному просторі воюють за людську свідомість.

Найбільш масштабним за обсягами контенту залишається російськоцентричний дискурс, який використовується в рамках ведення гібридної війни зі значними обсягами фінансування та залучення до роботи значної кількості фахівців (Rafalskyi, 2015).

Для впливу пропагандисти 3 Кремля обрали надійний інформаційнокомунікативний інструментарій - спотворення реальної картини, деморалізація ворога, створення фейків, фінансування, так званих «тролів» (Boiko, 2017). I чим абсурднішою була і є поширена дезінформація, тим сильнішим - ефект. Наприклад, 12 липня 2014 р. на Першому російському телеканалі вийшов сюжет про нібито розіп'ятого українськими силовиками хлопчика. Абсолютна брехня була миттєво 
розповсюджена іншими російськими ЗМІ та поширена у соцмережах. Пропаганда тиражувала окремий вигаданий факт як закономірність. Таким чином, протягом трьох років Росія вибудовує на світовій арені образ українського солдата-ката (Rosiiski ZMI vzialy interviu...).

Досить активно російські агресори використовують і заборонені технології 25-кадру, що вважаються небезпечними методами психотропної дії. Три роки тому СБУ опублікувало відеофрагмент випуску новин на телеканалі «Росія-24», в якому використовується маніпулятивна технологія. Протягом усього випуску про події в Одесі 2 травня 2014 р. в куті екрана з'являються малопомітні написи: «підпал: «Правий сектор», «людей убивають бандерівці», «нацгвардія - вбивці» (Rosiia-24).

У серпні 2017 р. на цьому самомуж каналі вийшов 4-хвилинний репортаж, в якому про фестиваль «Бандерштат» розповіли як про місце, де пропагують неонацизм та вчаться розбирати зброю (Zhurnalistku Rossii-24 vydvorili...). Насадження кліше «кривавих бандерівців» - це створення стереотипу, який інтегрується у вже існуючу картину світу і змінює $і 1$.

Ще одним з найбільш поширених заходів здійснення психологічного тиску став так званий «телефонний тероризм», тобто телефонні дзвінки з інформацією про замінування місць масового скупчення людей (торгівельні центри) або об'єкти інфраструктури (вокзали). Такі новини були особливо «популярними» впродовж 2014-2015 pp. (Pocheptsov, 2014).

На жаль, навіть викриття неправди і брехні 3 боку прокремлівських медійників не дає результату. Адже головне у гібридній війні - поширити сумнів, який рано чи пізно у голові «зазомбованих» перетворюється на погляд. Зупинити ці процеси зараз дуже складно, бо вони розпочалися задовго до військового наступу $\mathrm{i}$ базувалися на специфіці інформаційного середовища Сходу України. Російські телеканали були і залишаються джерелом політичних новин для 78 \% жителів Сходу та Півдня України (Telebachennia yak dzherelo politychnykh novyn...).

Не останню роль у деструктивному інформаційного впливі відіграє медійна неграмотність населення як України, так і Росії.

Ефективність такої інформаційно-пропагандистської кампанії важко переоцінити. За результатами соцопитування Київського міжнародного інституту соціології за три місяці 2014 р., 3 лютого по травень, чисельність позитивно налаштованих до України громадян скоротилася $366 \%$ до $35 \%$, а кількість негативно налаштованих росіян зросла з 26 до $49 \%$ (Kyivskyi mizhnarodnyi instytut sotsiolohii).

Ще 3 моменту анексії Криму (а за деякими даними - з часів Свромайдану) Росія потужно використовувала ІКТ як складову своєї гібридної війни проти нашої держави. Відповідно, убезпеченість кіберпростору держави від атак, від використання його проти інтересів національної безпеки та оборони одне $з$ пріоритетних завдань для країни. Наголосимо, що саме IKT, тобто свідомий, 


\section{ЗОВНІШНІ ІНФОРМАЦІЙНО-КОМУНІКАТИВНІ ВПЛИВИ: \\ ВИКЛИКИ ДЛЯ УКРАЇНИ)}

цілеспрямований та ефективний вплив на зміст, інтенсивність, напрями політичної комунікації, внаслідок чого кожен з їі елементів отримує власну користь, і є на сьогодні потужним інструментом ведення інформаційних воєн у світі (Yak shtuchno stvorene slovospoluchennia...).

Російська Федерація повною мірою використовує можливості медіа, маніпулюючи настроями населення. Саме таким чином відбувається поширення сепаратистських настроїв та просування ідеї «Новоросії», а також формування негативного образу української влади та військових, що стало однією з причин відокремлення територій Луганської та Донецької областей.

Інформаційно-комунікативний вплив здійснюється за допомогою радіо, телебачення та Інтернету (блоги, соцмережі, новинні портали та ін.). Новинні ресурси РФ систематично публікують матеріали про «звірства» українських військових. Нижче наведено декілька прикладів. Так, зокрема, на сайті «Новини Донецької Республіки» (від 23. 04. 2018 р.) вийшов матеріал, автор якого повідомив, що «українські силовики за добу 32 рази порушили режим припинення вогню», внаслідок чого є вбиті та поранені серед цивільного населення.

Варто згадати більш демонстративніші приклади. Так, на каналі ОРТ у 2014 р. показували сюжет про те, що українські бійці отримали наказ вбивати мирне населення, а воюють за обіцянку отримати винагороду - «клаптик землі та двох рабів».

Тоді ж телеканал РЕН-ТВ масово поширював сфабриковану інформацію про «нову Хатинь», коли в селищах Саурівка і Степанівка Донецької обл. бійці української Нацгвардії нібито влаштовували безчинства і вбивали всіх чоловіків, а жінок гвалтували. Також проросійські 3MI постійно створюють сюжети про українську владу у відредагованому вигляді, вириваючи їх 3 контексту (Feik: "Saurovskaya reznya" Natsgvardiei).

Наприклад, у нас досі триває обговорення проекту Закону України «Про прощення»: пропозиції щодо притягнення до відповідальності військовослужбовців Збройних сил України, які вчинили злочини в інтересах держави-агресора, а також громадян України, що вступили на службу в армію держави-агресора, незаконні збройні формування або військово-комерційні компанії, а також брали участь у бойових діях як найманці, залежно від тяжкості злочину. На сайті «Новини Донецької Республіки» (від 24.04.2018 р.) про це повідомляється так: «Згідно з українським законопроектом «Про прощення» 95 тисяч жителів Донбасу і Криму повинні понести кримінальну відповідальність». На сайті «РІА Новини» (від 24.04.2018р.) повідомлялося, що «США навмисно спотворюють положення воєнної доктрини Росії».

Російськими спецслужбами здійснювалися також спроби дискредитувати мобілізацію українських військовослужбовців шляхом поширення чуток у соціальних мережах про нібито затримання юнаків як потенційного «гарматного 
м'яса» на вулицях з метою їх примусового відправлення до зони ATO (Rossiiskie spetssluzhby pytayutsya diskreditirovat'...).

Також російські ЗМІ постійно повідомляли про «переваги» відокремлення ДНР та ЛНР від України і «звільнення від київської хунти» (обіцянки величезних російських пенсій, майже безкоштовного газу, неймовірного економічного підйому, націоналізації підприємств і кредитних канікул).

До комунікативних стратегій, які Росія здійснює на території України, належать:

- розділення (анексія Криму та сепаратистська діяльність на сході України);

- деморалізація (поширення російськими спецслужбами у соціальних мережах повідомлень про те, що українські юнаки $є$ для української влади винятково «гарматним м'ясом»);

- звинувачення ворога у звірствах (описи сцен жорстокості редставників української Нацгвардії щодо мирного населення) (Isakova, 2014).

ІКТ РФ наразі суттєво впливають на мешканців східних областей (Донецька і Луганська обл.), адже на всіх російських телеканалах, у новинних сюжетах показується сфальсифікована інформація, яка має на меті ввести в оману жителів ДНР та ЛНР.

Так, медіа РФ звинувачують українських військовослужбовців і фашизмі та пригніченні прав жителів східних областей. Російські телеканали систематично дезінформують своїх глядачів, випускаючи в ефір сюжети обстрілів 3 боку українських військових, показуючи їх агресорами, хоча насправді сюжет був взятий 3 відеогри, з'являються певні нові персонажі, які заявляють, що українські бійці отримали наказ на обстріл мирного населення за певну винагороду.

У соціальних мережах з'являються фальшиві фото, які нібито показують звірства, які відбуваються в Україні. 3 усіх російських телеканалів звучить інформація про те, як було б добре від`єднатися від України і стати частиною великої та могутньої Російської Федерації. Ідеться про високий рівень заробітної плати та гідну пенсію, стрімкий економічний підйом, низькі ціни на газ і тощо.

Г. Почепцов у своїй книзі «Інформаційні війни» зазначає, що «Сучасні інформаційні війни - це квазіагресивний інструментарій мирного життя, а не лише збройного конфлікту між державами. І постійний розвиток інформаційного простору продукує нові можливості для застосування цього інструментарію» (Pocheptsov, 2015). Окрім того, автор наголошує, що саме 3 появою Інтернету інформаційні війни набрали нових обертів.

3 кожним роком проблема застосування Росією комунікативних технологій проти інших країн зростає. Згідно з дослідженнями О. Астахова «Образ Росії в друкованих ЗМI України напередодні Майдану» (Astakhov, 2017), ще в 1990-х рр. Росія значно домінувала в українському інформаційному просторі. 


\section{ЗОВНІШНІ ІНФОРМАЦІЙНО-КОМУНІКАТИВНІ ВПЛИВИ: \\ ВИКЛИКИ ДЛЯ УКРАЇНИ)}

У цей показник включаються телепродукція, радіоефіри, шоу-бізнес та друковані ЗМІ. На думку вченого, РФ змогла досягти цього як за допомогою державного фінансування випуску відповідної російської продукції, так і через дії потужного лобі серед українських (за громадянством) політиків і чиновників, які саботували підтримку випуску української продукції.

Ситуація, що склалася в Криму та на Донбасі, відбулася саме через те, що довгі роки в цих регіонах не було достойної альтернативи російській пропаганді, яка тривалий час надходила звідусіль.

Дослідник А. Гервас стверджує, що приблизно з 2000-х рр. в Україні за російські гроші створювалися організації та рухи, які виконували ідеологічну функцію: псевдоветеранські організації, спортивні молодіжні псевдопатріотичні рухи на Сході України, чимало вихідців з яких у 2014 р. стали членами озброєних угруповань сепаратистів, організація так званих історичних реконструкторів. У цьому ж дослідженні автор стверджує, що приблизно в той самий час російські політтехнологи охоплювали велику частку українського ринку реклами, що призвело до нав’ язування українцям радянсько-російського менталітету.

Останнім часом досить потужним інструментом маніпуляції стали соцмережі «ВКонтакте» та «Facebook», на яких створюються та популяризуються спільноти, які нав'язують учасникам кліше пропаганди Кремля. Усі спроби української влади обмежити доступ українців до провокативної інформації зводяться нанівець, бо такий контент вже почали створювати навіть деякі жителі України. Згідно 3 дослідженням Центру медіакомунікацій «Нова Україна» (Telebachennia yak dzherelo politychnykh novyn...), у період з 28 лютого до 4 квітня 2014 р. виявлено факти активного використання російською пропагандою такого інструменту, як інтернет-мем. У вказаний період у проаналізованих ЗМІ було виявлено близько 3 тис. оригінальних новин i статей, уяких вживався штучний інтернет-мем «вежливые люди» - кліше російської пропаганди для позначення окупаційних військ, які висадилися в Криму без розпізнавальних знаків.

Метою інформаційної агресії $\epsilon$ не стільки захоплення територій, скільки захоплення свідомості опонентів, досягнення нейтралітету з боку однієї частини населення та отримання підтримки з боку іншої. Також вона є одним з основних, а можливо, навіть головним елементом так званої гібридної війни.

Росія фактично веде відкриту війну 3 кінця 2013 р., і 3 кожним днем інтенсивність цієї війни зростає. Для досягнення своїх цілей вона використовує ряд маніпуляційних технологій, які так чи інакше можна доволі легко помітити у кожному випуску російських новин. Розглянемо найяскравіші $з$ них:

- введення нових термінів та прийомів, а також існуючих у суспільстві забобонів, щоб наділити певні явища чи групи людей негативною або позитивною ознакою; 
- зловживання статистикою. Якщо у людини хороша пам'ять та гарні ораторські здібності, то вона може задавити будь-які аргументи цифрами. Сьогодні це стає сильною зброєю - особливо в контексті соціології, де відбувається посилання на думку більшості;

- зміна «порядку денного». Маніпулятори обирають з переліку подій ті, які $є$ найбільш корисними для них. Так, через ЗМІ підтримується високий рівень напруги навколо потрібної теми;

- посилання на анонімні джерела. Робиться це для того, щоб надати деяким твердженням більшої достовірності: розкривається інформація, доступна одиницям, що залучає людину в середину процесу;

- надання можливості висловитися експертам. Як і в минулому випадку, це надає твердженням більшої достовірності, адже в очах аудиторії експерти наділені таємним та унікальним знанням - ким би ці експерти не були;

- занурення в легкий транс. Звуковий чи відеоряд присипляє свідомість, через що інформація перестає сприйматися критично;

- залякування альтернативним сценарієм. Типу «зараз все не дуже добре, та може бути ще гірше». Так, Росія в будь-якій халепі посилається на Україну, адже «хай у нас не все добре, та в Україні ще гірше».

Сьогодні техніки маніпуляцій з боку Росії постійно вдосконалюються, тож насамперед важливо не те, що говорять, а те як говорять.

Проблема використання інформаційно-маніпулятивних технологій Російською Федерацією в процесі захоплення Кримського півострова наразі $€$ надзвичайно актуальною з огляду на вкрай негативні наслідки їх деструктивного впливу на свідомість громадян як України, так і світу в умо- вах розгортання воєн нового типу - гібридних воєн. Відповідно застосування новітніх гібридних засобів проведення актів агресії до іншої держави із залученням потужного арсеналу інформаційних заходів вимагає суттєвого аналізу цієї проблеми задля виявлення первинних ознак інформаційної агресії і запобігання їм у майбутньому.

У книзі Д. Прокоф'єва «Інформаційна війна й інформаційна злочинність» визначається: «інформаційна війна - це дії, започатковані для досягнення інформаційної переваги шляхом завдання шкоди інформації, процесам, що базуються на інформації й інформаційних системах супротивника при одночасному захисті власної інформації, процесів, що базуються на інформації й інформаційних системах» (Slyvka).

Основні методи інформаційної війни - блокування або спотворення інформаційних потоків та процесів прийняття рішень супротивника. Найчастіше інформаційні війни ведуться на міжнародному рівні. Вже не один рік інформаційну війну проти України веде Росія. Ця держава постійно провокує гучними заявами український уряд та і просто зневажливо ставиться до українців у своїх 


\section{ЗОВНІШНІ ІНФОРМАЦІЙНО-КОМУНІКАТИВНІ ВПЛИВИ: \\ ВИКЛИКИ ДЛЯ УКРАЇНИ)}

інформаційних матеріалах. У веденні інформаційної війни Росія застосовує певні IKT.

Таким чином, у зв'язку з глобальним поширенням інформаційних технологій у всі сфери нашого життя аналогічна підривна діяльність, якщо вона успішна, може завдати збитків, які можна порівняти 3 вибухом декількох атомних бомб. Це може деморалізувати й дезорганізувати противника, не застосовуючи при цьому звичайних озброєнь і жодного солдата.

Застосування інформаційних технологій задля маніпулювання настроями громадян у рамках проведення інформаційно-психологічних акцій Росії, націлених на території України, призвело до таких результатів: зміни свідомості більшості населення східних областей i, зокрема, виникнення у донеччан відчуття страху перед радикально налаштованими жителями Західної України - «бандерівцями», страху перед центральною владою в Києві - «хунтою»; страху перед втручанням європейських та американських політиків. Отже, ІКТ є не лише рупором певних політичних сил, але і безпосереднім джерелом підбурювання до насильства стосовно окремої національної меншини, що яскраво ілюструє ситуація інформаційної війти між РФ та Україною.

Значна кількість жителів «ДНР» та «ЛНР» піддаються впливу російської пропаганди і вважають, що від'єднання від України і насправді змінить рівень життя на краще. Отже, можемо спостерігати, що сучасна російська пропаганда досить суттєво впливає на стан сучасної України. Вона спирається на відповідні соціальнопсихологічні дослідження i методи ведення, розвинені інформаційно-технічні ресурси, адміністративно-політичне забезпечення, охоплення значної частини населення багатьох країн і досить високий рівень фінансування. Сьогодні можна прогнозувати довготривалий і агресивний характер ведення російської пропаганди в міжнародному масштабі, інформаційно-комунікативні методи, які вона використовує не тільки на адресу України, а й інших країн світу, є досить різноманітними та агресивними. Усе це має спрямованість на маніпулювання свідомістю громадян України й громадян інших країн, дестабілізацію ситуації в різних частинах світу, дискримінацію органів влади, внутрішньої та зовнішньої політики, просування власної позиції на підконтрольній їй території.

На інформаційні атаки Російська Федерація витрачає багато сил та ресурсів. До сьогодні продовжується дослідження та виведення нових засобів та способів маніпуляцій. Щодня ми чуємо велику кількість новин (навіть з багатьох українських 3МI), які налаштовують споживачів, які не вміють критично мислити, проти України. Через це українське суспільство схильне до розколів, як це сталося на Сході України.

Висновки. Отже, можна зробити висновки, що військовим діям на території України передували роки підготовки та створення сприятливого інформаційного поля. Інформаційно-комунікативні технології, що застосовує Росія, спрямовані 
не тільки на українське населення, але також і на російських громадян та західну аудиторію. Це дає змогу російській владі отримувати схвалення своїх громадян на військові дії і відволікати увагу європейської спільноти від подій в Україні.

Росія активно застосовує увесь спектр методів та способів поширення інформації, який пропонує сьогодні науково-технічний прогрес. Вагомим джерелом впливу на маси сьогодні $\epsilon$ вже не тільки телебачення, як це було на початку приходу до влади В. Путіна, але й соціальні мережі та блоги. Збільшення кількості та якості каналів передачі інформації закономірно призводить до того, що ними передається також і брехня та пропаганда.

Інформаційно-комунікативний вплив РФ проти України підтримується фінансовими та технологічними засобами могутньої тоталітарної держави, а тому протистояти йому досить непросто. Важливо розуміти, що ліквідація наслідків російської брехні - справа не одного року. Проведення власної пропаганди не може бути ефективним виходом для України, оскільки це всього лише замінює одну маніпуляцію іншою, коли важливо навчити громадян критично мислити та не сприймати будь-яку інформацію, побачену чи почуту в Інтернеті, як достовірну. Основи інформаційної грамотності та інформаційної безпеки - це ті заходи, яким потрібно навчати та прищеплювати громадянам, починаючи зі школи.

\section{References:}

1. Astakhov, O. (2017). 'Obraz Rosii v drukovanykh ZMI Ukrainy naperedodni Maidanu. Rostov-na-Donu' [The image of Russia in print media of Ukraine on the eve of the Maidan. Rostov-on-Don]. // Problemy nacional'noj strategii [Problems of the national strategy], no. 4 (43), pp. 94-108.

2. Boiko, M., (2017). Heorhii Pocheptsov:'Viina chetvertoho pokolinnia - tse viina kultur' [Heorhii Pocheptsov: The Fourth Generation War is the War of Cultures]. DetectorMMedia, [online] Available at:<http://detector.media/withoutsection/article/123918/2017-03-09-georgii-pocheptsovviina-chetvertogo-pokolinnya-tse-viina-kultur/> [Accessed 20 November 2018].

3. Feik: "Saurovskaya reznya" Natsgvardiei [Fake: 'Saurov Massacre' by National Guard]. (2014). StopFAKE.org, [online] Available at:<http://www.stopfake.org/fejksaurovskaya-reznya-natsgvardiej/> [Accessed 27 November 2018].

4. Isakova, T. O. (2014). 'Informatsiino-komunikatyvni tekhnolohii rozpaliuvannia mizhnatsionalnykh konfliktiv: dosvid porivnialnoho analizu' [Information and communication technologies of incitement of inter-ethnic conflicts: the experience of comparative analysis]. Stratehichni prioritety [Strategic priorities], no. 4(33), pp. 113-118.

5. Kyivskyi mizhnarodnyi instytut sotsiolohii [Kyiv International Institute of Sociology], [online] Available at: $<\mathrm{http}: / /$ www.kiis.com.ua/?cat=search\&lang=ukr\&searchstring=\%EF\%EE\%E7\%E8\%F2\% 


\section{ЗОВНІШНІ ІНФОРМАЦІЙНО-КОМУНІКАТИВНІ ВПЛИВИ: \\ ВИКЛИКИ ДЛЯ УКРАЇНИ)}

$\mathrm{E} 8 \% \mathrm{E} 2 \% \mathrm{ED} \% \mathrm{EE}+\% \mathrm{ED} \% \mathrm{E} 0 \% \mathrm{~EB} \% \mathrm{E} 0 \% \mathrm{~F} 8 \% \mathrm{~F} 2 \% \mathrm{EE} \% \mathrm{E} 2 \% \mathrm{E} 0 \% \mathrm{ED} \% \mathrm{E} 8 \% \mathrm{~F} 5 \& \mathrm{start}=30>$ [Accessed 29 November 2018].

6. Mahda, Ye. (2015). Hibrydna viina. Vyzhyty i peremohty [Hybrid War. Survive and win]. Kyiv: Vivat.

7. Pocheptsov, H. (2014). 'Rosiia i Ukraina u spivstavlenni yikh komunikatyvnopropahandystskykh mozhlyvostei' [Russia and Ukraine in comparing their communicativepropaganda capabilities]. MediaSapiens, [online] Available at:<http://osvita.mediasapiens.ua/material/33291> [Accessed 21 November 2018].

8. Pocheptsov, H. (2015). Suchasni informatsiini viiny [Modern information wars]. Kyiv: Kyiv-Mohyla Academy.

9. Rafalskyi, O.O. ed. (2015). Politychni aspekty kryzy na Donbasi: diahnostyka stanu ta napriamy vrehuliuvannia. Analitychna dopovid [Political aspects of the crisis in the Donbass: diagnosis of the state and directions of regulation. Analytical Report]. Kyiv: I. F. Kuras Institute for Political and Ethnic Studies of the National Academy of Sciences of Ukraine.

10. Rosiia-24, [online] Available at:〈http://live.russia.tv/index/index/channel_id/3> [Accessed 26 November 2018].

11. 'Rosiiski ZMI vzialy interviu u rozpiatoho v Sloviansku khlopchyka' [The Russian media interviewed the Slavic boy who was crucified]. (2014). UaReview, [online] Available at: $<$ http://uareview.com/slovyansk-hlopchyk/> [Accessed 23 November 2018].

12. 'Rossiiskie spetssluzhby pytayutsya diskreditirovat' mobilizatsiyu v Ukraine SNBO' Russian special services are trying to discredit mobilization in Ukraine - the NSDC]. (2014). Segodnia [Today], [online] Available at:<http://www.segodnya.ua/ukraine/rossiyskie-specsluzhby-pytayutsyadiskreditirovatmobilizaciyu-v-ukraine-snbo-541015.html> [Accessed 25 November 2018].

13. Slyvka, V. Informatsiina viina proty Ukrainy: mif chy realnist? [Informational war against Ucraine: myth of reality?], [online] Available at: $<$ http://intkonf.org/slivka-vv informatsiyna-viyna-proti-ukrayini-mif-chi-realnist/> [Accessed 26 November 2018].

14. Stratehiia zabezpechennia kiberbezpeky $\mathrm{v}$ hibrydnii viini [Cybersecurity strategy in the hybrid war]. (2018). Lexinform, [online] Available at: <https://lexinform.com.ua> [Accessed 28 November 2018].

15. Szwed, R. ed. (2016). Framing of the Ukraine-Russia conflict in online and social media. Riga: NATO Strategic Communications Centre of Excellence.

16. Telebachennia yak dzherelo politychnykh novyn - zahalnonatsionalne opytuvannia [Television as a source of political news - a nationwide poll]. (2014). Fond «Demokratychni initsiatyvy» im. Ilka Kucheriva, [online] Available at:<http://www.dif.org.ua/ua/polls/2014_polls/telebachennja-jak-dzherelopolitichnihnovin---zagalnonacionalne-opituvannja.htm> [Accessed 27 November 2018].

17. Yak shtuchno stvorene slovospoluchennia infikuvalo ukrainski ZMI [How artificially created the phrase was infected by Ukrainian mass media]. "Nova Ukraina" 
Instytut stratehichnykh doslidzhen ["New Ukraine" Institute for Strategic Studies], [online] Available at: <http://newukraineinstitute.org/new?id=396> [Accessed 28 November 2018].

18. Zakirov, M. (2017). 'Suchasni informatsiino-komunikatsiini tekhnolohii yak faktor evoliutsii sotsialno-politychnykh vidnosyn' [Modern information and communication technologies as a factor of the evolution of socio-political relations]. Naukovi pratsi Natsionalnoi biblioteky Ukrainy imeni V. I. Vernadskoho [Scientific works of the National Library of Ukraine named after. V. I. Vernadsky], issue 46, pp. 11-30.

19. 'Zhurnalistku Rossii-24 vydvorili posle Bandershtata' [Journalist of Russia-24 expelled after Bandershtat]. (2017). Korrespondent.net, [online] Available at:<http://korrespondent.net/ukraine/3877498-zhurnalystku-rossyy-24-vydvoryly-poslebandershtata> [Accessed 24 November 2018].

๑ Кочубей Л. О., 2019 